\title{
EFFICIENT AND SUSTAINABLE IMPROVEMENT OF A SYSTEM OF PRODUCTION AND COMMERCIALIZATION OF ESSENTIAL MOLLE OIL (SCHINUS MOLLE)
}

\author{
Raquel Medina Rodríguez \\ EUPG Escuela Universitaria de Posgrado - Universidad Nacional Federico Villarreal, (Perú). \\ E-mail: rmedina@uni.edu.pe ORCID: https://orcid.org/0000-0002-3311-7171

\begin{abstract}
Jorge Luis Breña Oré
National University of Engineering UNI, (Perú).

E-mail: jorge.brena.o@uni.edu.pe ORCID: https://orcid.org/0000-0001-6450-7052
\end{abstract}

Doris Esenarro Vargas Specialized Institute for Ecosystems and Natural Resources Research (INERN)

Ricardo Palma University - URP, (Perú).

E-mail: desenarro@unfv.edu.pe ORCID: https://orcid.org/0000-0002-7186-9614

Recepción: 13/07/2021 Aceptación: 02/11/2021 Publicación: 24/11/2021

\section{Citación sugerida:}

Medina, R., Breña, J. L., y Esenarro, D. (2021). Efficient and sustainable improvement of a system of production and commercialization of Essential Molle Oil (Schinus Molle). 3C Empresa. Investigación y pensamiento crítico, 10(4), 43-75. https://doi.org/10.17993/3cemp.2021.100448.43-75 


\section{ABSTRACT}

This research describes the relationships between the design of an efficient production cycle of metabolites from the Schinus molle plant, from extraction, processing, product formulation to the final disposal of its residues, and the project's environmental sustainability. The target population in this research was limited to small farmers-producers, marketers of natural products, technicians of the municipalities related to the MYPES, and students of engineering and careers related to agriculture and its processing, which were convened by a digital marketing system via Facebook, reaching a total of 300 participants in total. The sample chosen was non-probabilistic and consisted of 94 participants who gave their informed consent. The research design was pre-experimental. The results obtained through self-applied instruments in the control and experimental groups, under the application of an intervention program were subjected to hypothesis tests of mean differences with Wilcoxon statistics for related samples, reaching the general conclusion that the application of counseling and training programs in green business models based on the extraction and processing of Shinus molle essential oil positively influences the perceptions of stakeholders on the environmental sustainability of projects of this nature.

\section{KEYWORDS}

Environmental sustainability, Environmental concern, Ecological dimension, Sustainable development, Sustainability. 


\section{INTRODUCTION}

Ecological agriculture requires innovation processes in collaborative networks as an imperative need of a global nature framed in the complexity paradigm. This metamorphosis has to occur within a learning process (Tisenkopfs \& Kunda, 2015) that can re-energize the ecosystemic balances, which the endemic eagerness of compulsive consumerism has dangerously modified. Unfortunately, the discussion between organic and conventional agriculture is still antithetical and occurs at all levels in structuring state policies. While the former prioritizes ecosystem balances, the latter is based on increasingly demanding globalized markets (Ramón et al., 2012), suggesting the beginnings of the Anthropocene era (Meng et al., 2021).

Considering agroecology as a sustainable paradigm, there are still insufficient studies of micro, small business, and startup models that are congruent with production and marketing models within the agroecological rationale, with closed-cycle processes, within the paradigm of the circular economy about minimizing the production of waste and in any case to manage it for its reincorporation into the production chain.

The innovation process evaluated in this research is based on structuring collaborative networks between farmers, academia, and civil society, where experiences are exchanged and learning processes for transformation occur (Hediger \& Knickel, 2009). Unfortunately, while it is true that Peru is one of the most biodiverse countries, this importance has not helped the economic progress of farmers. Among the reasons given is the ineffectiveness of the state for its inability to articulate the regions with sectors of civil society and academia to promote the development and prosperity of farmers and rural areas.

According to the report published by IndustryARC (2019), in 2015 - 2022, the global essential oils market is expected to generate around USD 11.5 billion, at a CAGR of 10.1\% between 2016 and 2022 . Europe is the dominant market and is expected to be the major contributor to the global revenue of producing countries, owing to the revaluing trend of essential oils on a worldwide scale. 
This research aims to evaluate the feasibility of optimizing the value-added chain for Schinus molle essential oil producers, as a transversal axis, through an eco-business proposal within the paradigm of environmental sustainability and in a framework that promotes endogenous sustainable development.

\section{CONCEPTUAL FRAMEWORK}

\subsection{SUSTAINABLE DEVELOPMENT}

The construct refers to the unavoidable metamorphosis that must take place about how we relate to the world around us. Therefore, it is urgent to define agendas of a globalized nature, capable of assuming new paradigms to systemically address the economic-social-environmental triad dimension with a vision of politicians and strategists capable of permeating the social-environmental size to the principles of the economic extent (Cordera, 2017). i.e., "Governments face the complex challenge of finding the right balance between competing demands on natural and social resources, without sacrificing economic progress" (Strange \& Bayley, 2012, p. 33).

In the conceptualization of sustainable development, it is recognized that nature's reserves of availability are being depleted as a result of unplanned economic and technological development, which only takes into consideration current human needs and even within a habitual framework of compulsive consumerism to the detriment of nature. Consequently, it is urgent to initiate research projects with a different vision for the generation of applied knowledge in the state-academia-civil society triad to make the sustainability of agroecological projects viable (Gavito et al., 2017).

Sustainable development does not involve a stationary or static desired equilibrium state, specified through sustainability indicators as guarantee standards (Hediger \& Knickel, 2009). Instead, sustainable development is a dynamic, complex state immersed in the process of permanent change and reconfiguration based on the integrity of the system it represents (Hediger \& Knickel, 2009). 


\subsection{DIMENSIONS OF SUSTAINABLE DEVELOPMENT}

According to González (2012), four dimensions should be considered to address sustainable development. These dimensions are society, environment, culture, and economy, which present dynamic relationships due to the complexity of the construct. According to this approach, man, by constructing himself socially and culturally, transforms himself, achieving a new cultural environment. On the other hand, Larrouyet (2015) argues that sustainable development "implies advancing simultaneously in five dimensions: economic, human, environmental, institutional and technological" (p. 24). Therefore, the characterization of the sustainable development profile to be designed depends on the socio-cultural context characteristics of the nations.

The present research considers three dimensions of sustainable development, which should be assumed as a systemic and indissoluble triad: economy, society, and environment (Carro-suárez \& SarmientoParedes, 2017). Regardless of the context, the fundamental premise for the introduction of sustainable development in state policies must be examined from the theory of systems, evaluating it in the nondecreasing function of its inputs and outputs, with evolutionary and increasingly demanding concepts and measurements, based on a drastic change of people's culture, with binding state policies concerning all the dynamic and indissoluble relationships of the variables of environmental sustainability. Some of these interdependencies can probably be temporarily bypassed, but history shows that before long, some alarm or crisis calls for a return to the path of sustainable development.

While it is true that this article addresses sustainable development based on three dimensions (Artaraz, 2001), a reductionist and non-systemic perspective, which for many researchers has a utilitarian approach, it is urgent to evaluate the interdependencies between the three pillars, wherein a prevalent analysis it establishes that social welfare and economic welfare nurture each other in correspondence of univocal relationships and that they only become sustainable within a balanced and sustainable ecosystem in time and space (Carro-Suárez \& Sarmiento-Paredes, 2017). It is fundamental to understand complexity, based on the systemic model of sustainability (Kammerbauer, 2001), considering dynamic, 
diffuse relationships with a lot of uncertainty, since the stakeholders have conflicting interests and with a constitutive dominance of utilitarianism that intends to use the construct of Sustainable Development to perpetuate the market economy.

\subsubsection{ECONOMIC DIMENSION}

In the last decades, it can be observed that there has been a tendency to invoke the international community to develop state policies oriented to the sustainable development of countries. However, the term development alludes to its traditional context, economic development, which generates a conflict of interests between economic activity and the environment, with imprudent and foolish actions, such as assuming that nature is an inexhaustible source of resources and a bottomless sink for waste. Consequently, one of the weaknesses that must be reversed to achieve sustainable development is to rethink the structure of the state in such a way that the society-economy-environment triad restructures its principles from a market economy towards an environmental economy that can determine the guidelines of the modes of production, industrialization, and commercialization within environmental rationality in a relentless search for social equity (Carro-Suárez \& Sarmiento-Paredes, 2017). Among the factors that energize the irrational utilitarian Peruvian economy is the culture with a lack of national identity, the lack of knowledge generation, which leads to technological obsolescence of the productive capacity of agribusiness, poor land-use planning, which has been exacerbated by environmental conflicts generated by mining with a purely extractive approach, the lack of competitiveness at the global level, are the main factors responsible for the poor management of agriculture in Peru (Gavito et al., 2017).

The economic dimension from the sustainability approach should not continue to operate under the principle that nature is infinite and always tends to rebalance itself. The articulation of the economysociety-environment triad without prevalence levels (Balvanera et al., 2017) should lead us to propose models or paradigms under the perspective of environmental accounting where prevention comes before remediation. The practical vision of the ecological problem is to reduce pollution and, in any case, 
manage it for the final deposition considering the most negligible environmental impact. Within the field of an economy that assumes ecological liabilities, what is intended is the constant search for sustainable alternatives with atomic efficiency, use of renewable energies within a closed system of production. About ecological economics (Castiblanco, 2007) argues that "it is a scientific discipline that integrates elements of economics, ecology, thermodynamics, ethics, and other natural and social sciences to provide an integrated and biophysical perspective of the interactions that are interwoven between economy and environment." (p. 8)

\subsubsection{SOCIAL DIMENSION}

It can be considered one of the least addressed pillars in discussions in international forums on sustainable development. Lehtonen (2004) argues that the human talent capabilities approach and social capital are the underlying bases of the social dimension. However, their practical implementation is not fully realized, even though these approaches propose a cultural partner articulation that should consider social sustainability, based on equity, which should be a transversal axis or the center of the social dimension and, in this perspective, intergenerational equity (Lehtonen, 2004) should be considered as an additional factor. Likewise, it is not enough to view social confluences about the dynamics of socio-environmental conflicts and consider citizen participation with legitimate and horizontally based dialogue among stakeholders as a binding condition for environmental sustainability. It should be emphasized that discussion must begin by recognizing the perversity of the inequitable distribution of resources between business people and society and between man and nature.

Finally, of the seventeen objectives of sustainable development, it can be affirmed that equity, social justice, and environmental conservation are the fundamental pillars of sustainable development and these three objectives constitute part of the social dimension of sustainable development, with equity and ecological integrity being recent, where the first is one of the principles extensively studied because it is a global problem that requires solutions on a local-regional-international and intergenerational scale 
and is based on responsible management based on respect for all forms of ecosystemic life, preventing or mitigating all environmental problems, reducing inequality, the main problem in society due to the exploitation and degradation of man and therefore of the environment. Currently, efforts are being made to promote socio-culturally integrated communities, inclusive of the human-nature dyad, thus providing access to social and environmental justice as the underlying basis for a genuinely lasting sustainable development.

\subsubsection{ECOLOGICAL DIMENSION}

A relevant premise for analyzing ecological sustainability is the second principle of thermodynamics related to the tendency of systems to move spontaneously towards equilibrium (Kammerbauer, 2001). However, the complex character of ecosystems does not admit Cartesian generalizations about states of peace projected by man (Kay, 1991, cited in Kammerbauer, 2001).

Again, from the position assumed in the present research of moderate anthropocentrism, concerning this dimension, sustainability presumes an accounting that also values environmental assets and liabilities, with a sound and productive circular system, trying to imitate nature (Alvarado et al., 2020). In other words, it is urgent to introduce eco-designs in the modes of production based on rationality and environmental awareness.

The ecological dimension of sustainable development, about human beings, refers to the set of values, attitudes, and motivations that should govern the relations between society and nature and how these relations should be translated into systems of production and management of rational and closed-cycle productive resources, as well as in the regulation of individual and group behavior of humans, based on the consideration of all forms of ecosystemic life.

In the context of different social processes that perpetuate inequity and awareness of the confrontation between man and nature to the detriment of the environmental dimension of sustainable development, it is urgent to consider that the availability and potentiality of biogenetic resources are not infinite, 
nor that nature is a sink for its residues and that the uncontrolled predatory effects of natural man are reaching a state in which there is no return and nature and its internal ecological balance cycles will take actions to reestablish it without considerations of preservation of man and his future generations.

In this context, man's concepts of subsistence and entrepreneurial action must change his compulsive habits of consumption, which must undergo a metamorphosis of all his social systems of organization, production, commercialization, consumption, accumulation, transformation, and management of natural resources; as well as the deployment of his creative capacity to project himself beyond time and space always with considerations for otherness. At the same time, the concept of nature must include all sources and vital cycles of energy and biogenesis and other challenges that consider all living species, integrating everything in a single process of ecosystemic interrelations.

The decontextualization of the economy based on neoliberal utilitarianism has led to the unsustainability of the modern economy, and it is not enough to associate in the order of prevalence, the economyecology, or economy-social context binomial. Still, it is necessary to recover the web of dynamic and complex relationships of the economy-social context-ecology triad (Paredes et al., 2020). This article argues that recovering a contextual understanding of the economy is essential for sustainability. Indeed, the loss of the ecosystemic context is at the root of the unsustainability of our current economic activity. It is not enough to recover only the ecological or social context in which economic activity takes place. Sustainability challenges us to recover the links of a dynamic nature between the three dimensions of sustainable development (Kammerbauer, 2001).

\subsection{SCHINUS MOLLE}

The molle, called the Peru tree, is appreciated as a plant native to Peru that covered the entire region of Tahuantinsuyo at the time of the Inca Empire. During the conquest and the viceroyalty, it spread to Ecuador, Chile, and Bolivia and the North to Mexico and the USA. The molle grows naturally in the Peruvian Andes and is necessary for reforestation of very degraded areas because it resists drought, 
frost, slightly saline soils, and is not edible for livestock. It also thrives in stony soils and contributes to soil formation. It is ideal for use as a windbreak defense and in the registration of soil erosion. It is a wild tree that does not need irrigation for its growth usually grows next to the Tara or Guarango plant creating fencing structures as shade in parks, green areas, roads (Bautista, 2018).

It is widespread in Peru. Schinus molle Linnaeus grows in full sun in temperate and dry subtropical regions and develops in areas from sea level to 3500 masl. The average annual temperature for its development is $15-20^{\circ} \mathrm{C}$, with an average yearly rainfall of $300-360 \mathrm{~mm}$. However, it tolerates warmer temperatures and, once established, is extremely drought tolerant. It is also resistant to frost and temperatures as low as $-10^{\circ} \mathrm{C}$. In nature, it occurs in semi-arid wastelands, riverbanks, along riverbanks, and on slopes up to 2,400 m altitude. Sandy and well-drained soils are preferred, but it is tolerant to saturated, poorly drained and infertile soils. It is also susceptible to alkalinity and salinity. Molle plantations have shallow roots and can be fragile; therefore, they are likely to blow over or break their branches in solid wind and need protection from wind. According to the family to which the plant belongs, the edaphological conditions and the ripening stage of the fruits contain up to $5 \%$ of essential oils in fruits and $2 \%$ in leaves (Bautista, 2018).

\subsubsection{SCHINUS MOLLE ESSENTIAL OIL}

They are odoriferous volatile liquid fractions, generally obtained by steam distillation, maceration, extraction by supercritical fluids, and constituted by a complex mixture of terpenoid compounds whose most important applications are in the cosmetics industry, fragrances, and as a flavoring agent in the culinary industry (Bautista, 2018). The fruit and leaves of Schinus molle contain many bioactive compounds with pharmacological properties proven in multiple investigations in Peru, Mexico, among other Latin American countries. Forty-six compounds were identified by gas chromatography in the essential oil obtained by steam distillation of Schinus molle fruits, including nine monoterpene hydrocarbons, one 
aromatic compound, one aliphatic acid ester, two monoterpene esters, 16 sesquiterpene hydrocarbons, and 17 other sesquiterpenoids (Bernhard et al., 1983, cited in Lim, 2016).

The essential oil composition of Schinus molle fruits reports that the main compounds are $46.52 \%$ -phellandrene, $20.81 \%$-phellandrene, $8.38 \%$-terpineol, $4.34 \%$ pinene, $4.96 \%$-pinene, and $2.49 \%$ p-cymene, respectively (Bendaoud et al., 2010, cited in Lim, 2016).

\subsubsection{USES OF SHINUS MOLLE}

Among the most appropriate uses of the leaves or fruits can be mentioned as a flavoring agent because the whole plant has an intense characteristic odor due to essential oils. The cooking of leaves, branches, bark, and root is used for pale yellow dyeing of wool fabrics when alum is used as mordant, and the tonality can be changed, according to the type of mordant used (Bautista, 2018). The methanolic extract of Schinus molle leaves produces a complex mixture of metabolites, mainly constituted by 12 sesquiterpenoids, six tirucallane-type triterpenoids, and four flavonoids isolated from Schinus molle fruits exhibited antioxidant activity (Ono et al., 2008, cited in Lim, 2016). Among them, three flavonoids exhibited antioxidant activity almost identical to -tocopherol by the ferric thiocyanate method. One flavonoid showed a more substantial radical scavenging effect on 1,1-diphenyl-2-picrylhydrazyl than that of -tocopherol.

Among the pharmacological activities, the components of Schinus molle essential oil exhibits cytotoxic activity against a human hepatocellular carcinoma cell line (Lim, 2016). Also, the hexane extract of Schinus molle leaves produces antidepressant-like effects that seem to depend on its interaction with serotonergic, noradrenergic, and dopaminergic systems (Machado et al., 2007, 2008, cited in Lim, 2016). Further research indicated that the antidepressant-like effect of Schinus molle ethanolic extract is due to the presence of flavonoids, which was postulated to exert its antidepressant-like impact by increasing the availability of serotonin and noradrenaline in the synaptic cleft (Lim, 2016). 
The main pharmacological activity of Schinus molle essential oil is an antimicrobial activity because Schinus molle leaf oil exhibited maximum fungi harmful activity during the screening of some essential oils against some shared storage and animal pathogenic fungi (Bautista, 2018). On the other hand, the essential oil showed effective toxicity against animal pathogens and mild activity against storage fungi (Lim, 2016).

\section{METHODOLOGY}

According to the study's purposes, the type of research is classified as applied research. It is proposed to use the fundamentals of sustainable development to make proposals on an efficient and sustainable design of production and commercialization of products based on essential oils.

The level of research is explanatory-causal because the objective is to study the influence of an efficient and sustainable design of production and commercialization of products based on Schinus molle essential oil on the perceptions about the environmental sustainability of this type of agroecological business.

The research method used is hypothetical-deductive. It is intended to test the influence of an efficient and sustainable design of production and commercialization of products based on Schinus molle essential oil on perceptions of environmental sustainability.

The research design is pre-experimental. This type of design was carried out with a pre-test and post-test after applying for the training program in an efficient and sustainable model of production and commercialization of products based on Schinus molle essential oil to evaluate the variation of perceptions of environmental sustainability. The pre-experimental designs present a minimum degree of control, the manipulation of the independent variable is produced and what is intended is to observe its effects on the dependent variable. It should be noted that the difference with pure experimental designs is centered on the reliability assumed when establishing the control and experimental groups, according to Hernández et al. (2014), in this type of design, randomization is not introduced when assigning the 
experimental group since, due to logistical or other needs, unrelated to the experiment, they are chosen in a non-random manner. Therefore, the groups established for the research are not randomized and were covered by the quota sampling technique.

The formal and logical representation is:

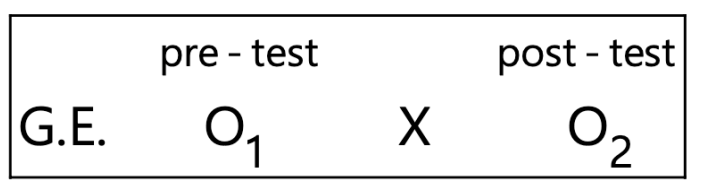

Legend:

$\mathrm{X}=$ Experimental variable: training program in the efficient and sustainable product design and commercialization of products based on Schinus molle essential oil.

$\mathrm{O} 1$ = Pre-test measurements: Environmental sustainability.

$\mathrm{O} 2$ = Post-test measurements: Environmental sustainability.

\subsection{SAMPLE}

\subsubsection{PLANT SAMPLE}

Schinus molle fruits were collected in the month of July 2019 in Huayucachi-Huancayo Junín, Luricocha-Huanta-Ayacucho, Huayllan-Pomabamba-Ancash, with a total weight of $50 \mathrm{~kg}$ (see Table 1). The protocol for each sample collected was to wash with potable water and dry outdoors for six days. After the natural drying time, they were packed in thick paper and cardboard box, to be sent to the Organic Chemistry laboratory of the Faculty of Chemical Engineering of the Universidad Nacional de Ingeniería. Finally, the sample was received at the organic chemistry laboratory, registering a net weight of $40 \mathrm{~kg}$. 
Table 1. Molle fruit harvesting zones.

\begin{tabular}{|c|c|c|c|c|c|c|c|}
\hline ID & Plant & Family & Part used & Place of collection & $\begin{array}{l}\text { The initial } \\
\text { weight of } \\
\text { collected }\end{array}$ & $\begin{array}{l}\text { sample Weight } \\
\text { of dry sample* }\end{array}$ & $\begin{array}{c}\text { Importance } \\
\text { of dehulled } \\
\text { and sieved } \\
\text { sample*. }\end{array}$ \\
\hline 1 & $\begin{array}{l}\text { Shinus } \\
\text { molle }\end{array}$ & $\begin{array}{l}\text { Anacardia- } \\
\text { ceae }\end{array}$ & Fruits & $\begin{array}{l}\text { Huayucachi-Huancayo } \\
\text { Junín }\end{array}$ & $10 \mathrm{~kg}$ & $9,4 \mathrm{~kg}$ & $8,0 \mathrm{~kg}$ \\
\hline 2 & $\begin{array}{l}\text { Shinus } \\
\text { molle }\end{array}$ & $\begin{array}{l}\text { Anacardia- } \\
\text { ceae }\end{array}$ & Fruits & $\begin{array}{l}\text { Luricocha-Huanta } \\
\text { Ayacucho }\end{array}$ & $8 \mathrm{~kg}$ & $7,5 \mathrm{~kg}$ & $6,4 \mathrm{~kg}$ \\
\hline 3 & $\begin{array}{l}\text { Shinus } \\
\text { molle }\end{array}$ & $\begin{array}{l}\text { Anacardia- } \\
\text { ceae }\end{array}$ & Fruits & $\begin{array}{l}\text { Huayllan-Pomabam- } \\
\text { ba-Ancash }\end{array}$ & $7 \mathrm{~kg}$ & $6,6 \mathrm{~kg}$ & $5,6 \mathrm{~kg}$ \\
\hline 4 & $\begin{array}{l}\text { Shinus } \\
\text { molle }\end{array}$ & $\begin{array}{l}\text { Anacardia- } \\
\text { ceae }\end{array}$ & Fruits & $\begin{array}{l}\text { Peso total de fruto de } \\
\text { Shinus molle a procesar }\end{array}$ & $25 \mathrm{~kg}$ & $23,5 \mathrm{~kg}$ & $20 \mathrm{~kg}$ \\
\hline
\end{tabular}

Source: own elaboration.

\subsubsection{STAKEHOLDER SAMPLE}

Considering that the stakeholder population is limited due to the sui generis nature of the project, in the context of Covid-19, the target population was limited to small farmers-producers, natural product marketers, technicians from the municipalities related to the MYPES, and students of engineering and careers related to agriculture and its processing, which were convened by a digital marketing system via Facebook, reaching 300 participants. Therefore, the sample chosen was non-probabilistic and consisted of 94 participants who gave their informed consent.

\subsection{ENVIRONMENTAL SUSTAINABILITY INSTRUMENT}

The development of the instrument was based on the research of Silva-Santamaría and RamírezHernández (2017), Becerril (2017), and De Los Rios-Carmenado et al. (2016), whose instruments were developed from others that have been used over the last 20 years in research on environmental sustainability, within the approach of the three most relevant dimensions of sustainable development: the economic dimension formed by three factors that collect information on productivity, producer welfare, and marketing; the social size that collect information on two factors, local-regional government 
and stakeholders and the ecological extent constituted by a single factor related to the sustainability of the project in general terms.

In developing the instrument, a self-application questionnaire was designed with a bipolar Likert scale, ranging from never to always with a total of 48 items. In addition to the three cross-cutting dimensions of environmental sustainability, the sociographic aspects of the sample elements were also considered.

The analysis of the instrument's internal consistency was statistically calculated by Cronbach's alpha with the SPSS-Statistics software, having carried out the verification by factors, dimensions, and by all the information collected by the instrument. Cronbach's alpha values are between 0.812 and 0.934 , values between acceptable and high for research works of this nature (Hernández et al., 2014). It should be noted that the correlations of the instrument-ecological dimension binomial are positive and more significant than the instrument-social dimension correlations, which in turn are higher than that of the instrument-economic dimension. Considering that the sample elements are constituted by 94 persons to whom the instrument has been applied in a pre-test and post-test, the internal consistency analysis indicates that the self-application of the device presents high internal consistency and high reliability of its results.

\subsection{EXPERIMENTAL PART}

\subsubsection{EXTRACTION OF THE ESSENTIAL OIL}

The experimental procedure for molle essential oil extraction was carried out with batches of $3.6 \mathrm{~kg}$ of molle fruits, an average molle actual oil extraction volume of $215.2 \mathrm{~mL}$, and an average extraction yield of $4.8 \%$ by mass. 


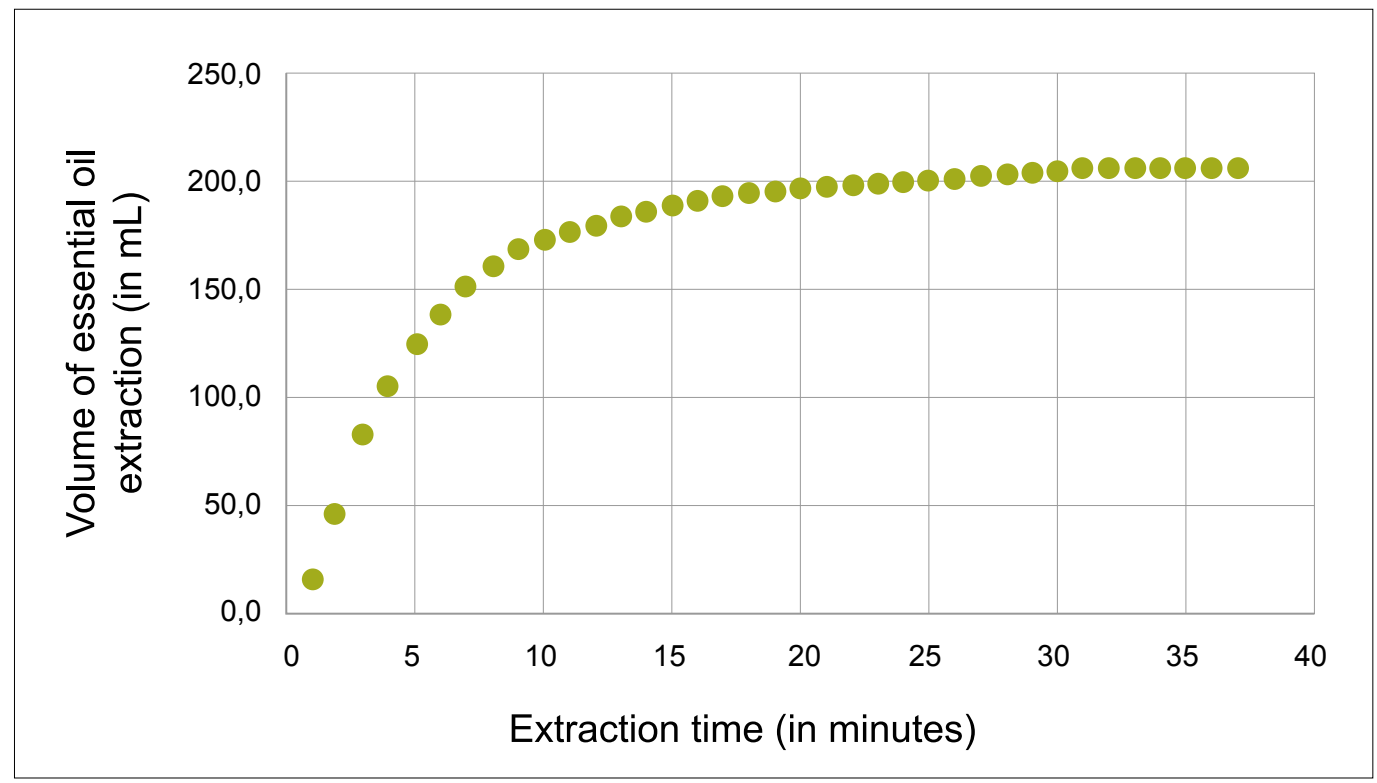

Figure 1. Extraction profile of Schinus molle L. essential oil.

Source: own elaboration.

The extraction procedure was carried out with steam extraction equipment with internal steam production of $16 \mathrm{~L}$ capacity. After a preliminary treatment of washing, drying, dehulling, and grinding, ground molle fruit with a particle diameter $<4 \mathrm{~mm}$, an average bulk density of $0.42 \mathrm{~kg} / \mathrm{L}$, and a power of $2000 \mathrm{~W}$ was obtained. Figure 1 shows the profile of the extraction curve extrapolating an average extraction time of 35 minutes, the optimum time of 21 minutes for the extraction of $97 \%$ of the essential oil.

\subsubsection{GREEN BUSINESS MODEL VALUE CHAIN}

The proposed production microindustrialization commercialization model is framed within the robust sustainability paradigm where "the substitutability of natural capital is seriously limited by ecological characteristics such as integrity, irreversibility, uncertainty and the existence of critical components of natural capital that make a unique contribution to human well-being" (Castiblanco, 2015, p. 4). 
The present research aims to establish a closed-cycle production and commercialization model about minimizing waste production and, in any case, to manage it for its reincorporation into the productive chain. This approach is framed within the guidelines of the eco-efficient output. It is aimed at promoting manufacturing processes based on prevention rather than remediation, where eco-efficiency is evaluated at each stage of the process about reducing energy and water consumption and reducing waste generation and, last but not least, to the proposal of adequate waste management until the formation of compost, closing the production cycle sustainably and sustainably, offering competitive products about quality.

Figure 2 shows the flow diagram of the closed-loop production cycle of the value chain of the business model based on the molle essential oil.

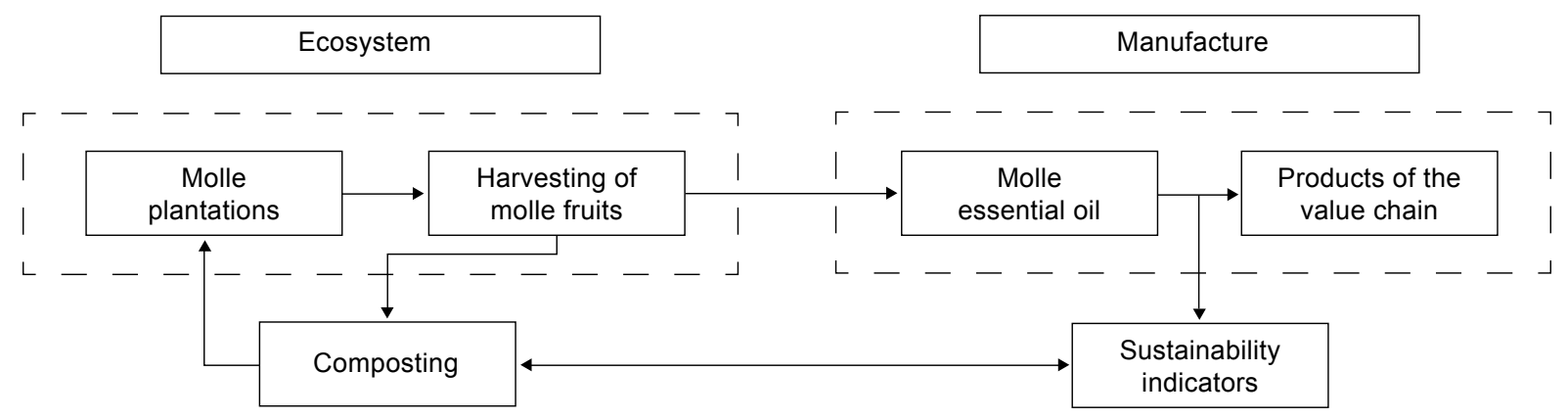

Ecoagriculture

Figure 2. Model for efficient and sustainable production and marketing of molle essential oil and its commercial products. Source: own elaboration.

In this context, we intend to contribute a grain of sand to the training of farmer-entrepreneurs in the central region of Peru, who require technical assistance to solve challenging problems, forge, outline prototypes and discover sustainable solutions, which is why they must add environmental, social and economic value to their proposals. 


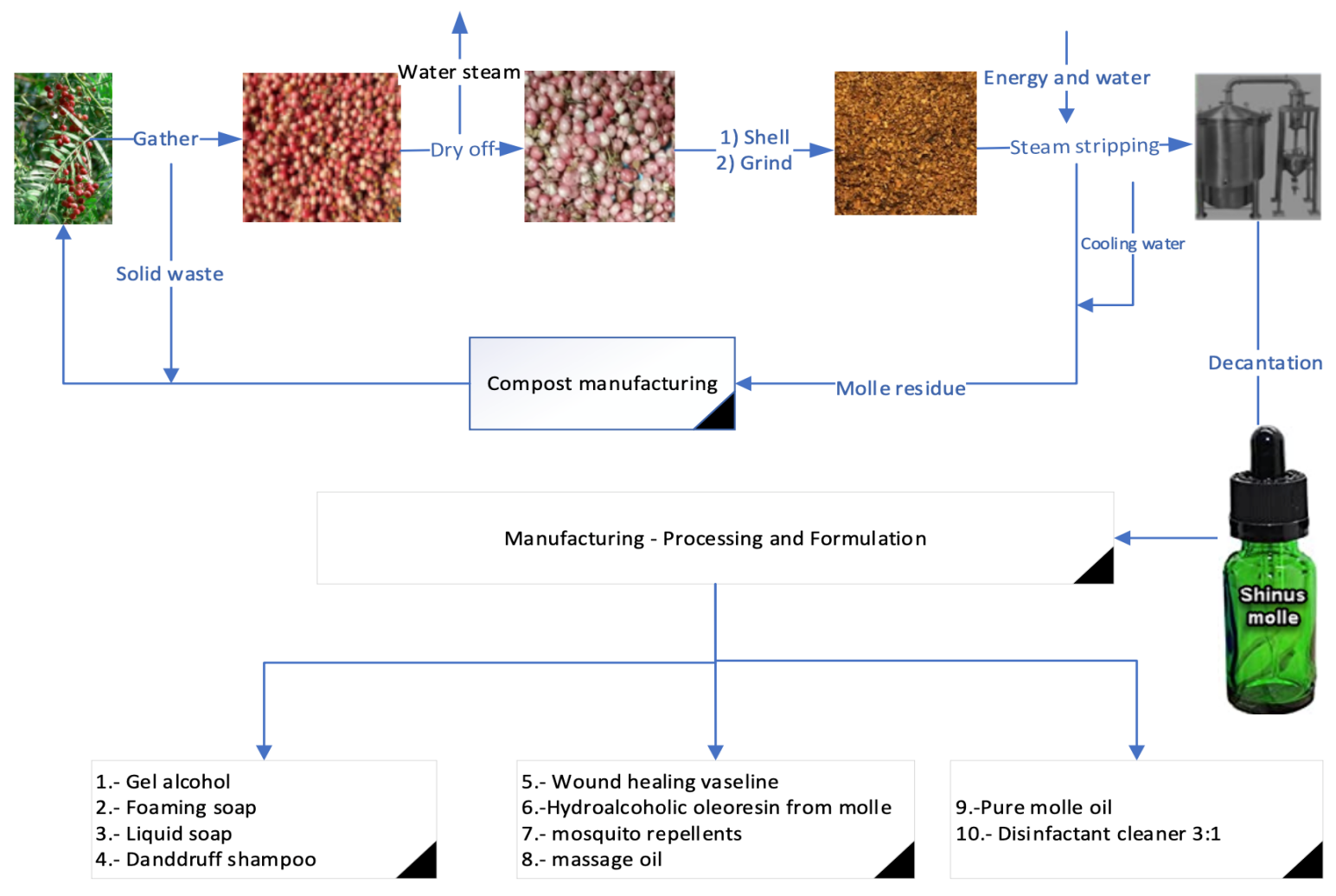

Figure 3. Closed production model for commercial products.

Source: own elaboration.

Figure 3 shows the production diagram of the whole business model. The agroecological model's sustainability is affiliated with a series of formalisms that include social, environmental, and economic aspects of the system (Castiblanco, 2015). The business model based on sustainable agriculture is based on an integrated management system of organic agricultural production processes, in that molle plantations do not require chemical pest control, maintain productivity naturally, protect green areas from pollution, robust rural smallholder farming systems (Altiere, 2018). The proposal is based on promoting, in a self-managed manner and with the support of academia and civil society, business models established 
based on natural agricultural resources under sustainable agriculture (Silva-Santamaría \& RamírezHernández, 2017).

Figure 3 shows the production cycle of Schinus molle essential oil and its transformation into commercial products within a closed process. The model is based on forming strategic alliances with agricultural associations, trade associations, state agencies, and universities. The value chain focuses on quality culture, which implies continuous technological and commercial development and innovation.

\section{RESULTS}

\subsection{RESULTS ON THE ECONOMIC DIMENSION}

Table 2 shows the descriptive statistics of the factors that make up the economic dimension, productivity, farmer welfare, and marketing, indicating a positive evolution of perceptions from the pre-test to the post-test.

Table 2. Descriptive statistics between the factors of the economic dimension.

\begin{tabular}{|c|c|c|c|c|c|c|c|c|}
\hline Factors & \multicolumn{2}{|c|}{ Factor: productivity } & Factor: Farmer welfare & Factor: marketing & \multicolumn{2}{|c|}{$\begin{array}{c}\text { Total average of the } \\
\text { economic dimension }\end{array}$} \\
\hline $\begin{array}{c}\text { Type of } \\
\text { test }\end{array}$ & Pre-test & Post-test & Pre-test & Post-test & Pre-test & Post-test & Pre-test \\
\hline Mean & 3,10 & 3,22 & 3,60 & 3,77 & 3,83 & 4,01 & 3,37 & 3,58 \\
\hline Median & 3,17 & 3,22 & 3,67 & 3,83 & 4,00 & 4,00 & 3,45 & 3,60 \\
\hline Mode & 3,00 & 3,11 & 3,67 & 3,67 & 4,00 & 4,00 & 3,80 & 3,35 \\
\hline Std. Dev. & 0,81 & 0,68 & 0,89 & 0,61 & 0,93 & 0,61 & 0,78 & 0,49 \\
\hline
\end{tabular}

Source: own elaboration.

Figure 4 shows the box-and-whisker plot for the results of the total economic dimension. Again, the graph shows an increase in the median relative to the perception between the pre-test and post-test on the green business model approach. 


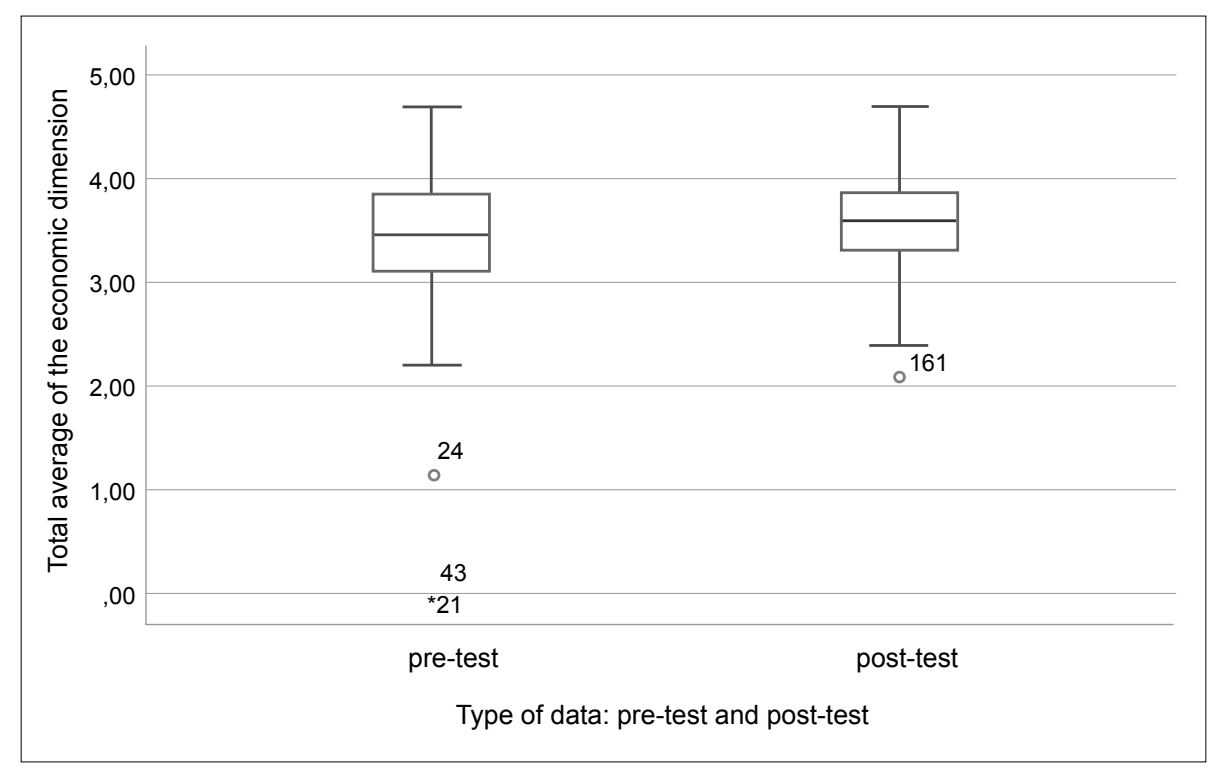

Figure 4. Box-and-whisker plot for the economic dimension.

Source: own elaboration.

The application of median comparisons with the Wilcoxon test for related samples shows a value of the Wilcoxon statistic of $\mathrm{Z}=-1.646$ with Sig. $=0.100$. The statistical test shows no statistically significant evidence to reject the null hypothesis of equality of medians. Consequently, it can be stated that there is no statistically reliable evidence to assume that the implementation of training programs in green business models influences the perception of the economic dimension of the instrument.

This result is related to the fact that green projects do not have a utilitarian media purpose; their objectives are medium or long term because, based on the knowledge of the consumption practices of the 21st century, the entrepreneurs of this type of project have a higher degree of environmental awareness and replace paradigms of media capitalization projects by others of capitalization in sustainable green assets in the future (Castañeda, 2014). 
One of the factors related to these results is centered on the influence exerted by the training program, with content focused on training with environmental responsibility, environmental awareness, environmental ethics, ecological rationality, with business models based on the circular economy, which promote economic-social-ecological sustainability (Velayos-Castelo, 2008).

In the opinion of Arias (2006), the business model to be implemented is based on the rational use of molle plantations that grow naturally and without significant care in the central zone of Peru, without encouraging the agro-industry that promotes monoculture and encouraged by compulsive consumerism. In the same line of conclusions as Castañeda (2014) it can be inferred that the economic dimension is of lesser weight for those stakeholders committed to environmentally sustainable projects because their concerns for the environment, before their problems for financial profits, underlie an impelling force of prognosis about the intentions of their undertakings and that is based on the "theory of planned behavior" (Velayos-Castelo, 2008). That is, projecting their decisions on the trends of the ever-increasing green consumer behavior.

While it is true that the implementation of technical assistance programs from universities to producers regarding the introduction of essential oils to agro-based business models is strategic, the perception of the respondents is not focused on the economic profitability that could cause the implementation of these projects, but are based on socio-environmental rationality.

\subsection{RESULTS ON THE SOCIAL DIMENSION}

The results in Table 3 show that the mean of the perception on the social dimension from a green business model approach has a valuation in the pre-test of the standard of 2.02 for the factor national, regional, and local government and 2.56 for the stakeholder's dimension and these statistics increase for the post-test. 
Table 3. Descriptive statistics among the factors of the social dimension.

\begin{tabular}{|c|c|c|c|c|c|c|}
\hline \multirow{2}{*}{$\begin{array}{l}\text { Factors } \\
\text { Type of test }\end{array}$} & \multicolumn{2}{|c|}{$\begin{array}{l}\text { Average of the social dimension: na- } \\
\text { tional-regional-local government(D4): } \\
\text { G21-G28 }\end{array}$} & \multicolumn{2}{|c|}{$\begin{array}{l}\text { Average of the social dimension: } \\
\text { stakeholders (D5): T29-T31 }\end{array}$} & \multicolumn{2}{|c|}{$\begin{array}{l}\text { Total average of the } \\
\text { social dimension }\end{array}$} \\
\hline & Pre-test & Post-test & Pre-test & Post-test & Pre-test & Post-test \\
\hline Mean & 2,02 & 2,58 & 2,56 & 2,77 & 2,17 & 2,60 \\
\hline Median & 2,00 & 2,50 & 2,67 & 2,83 & 2,18 & 2,63 \\
\hline Mode & 1,50 & 2,25 & 3,00 & 3,00 & 2,55 & 2,73 \\
\hline
\end{tabular}

Source: own elaboration.

The application of median comparisons with the Wilcoxon test for related samples shows a value of the Wilcoxon statistic of $Z=-4.044$ with Sig. $=0.000$, as shown in Figure 5. Thus, the statistical test indicates statistically significant evidence to reject the null hypothesis of equality of medians. Consequently, it can be concluded that the application of the training program in green business models has a positive influence on the perception of the social dimension about the fact that strategic farmer-civil societyuniversity alliances make green business projects viable.

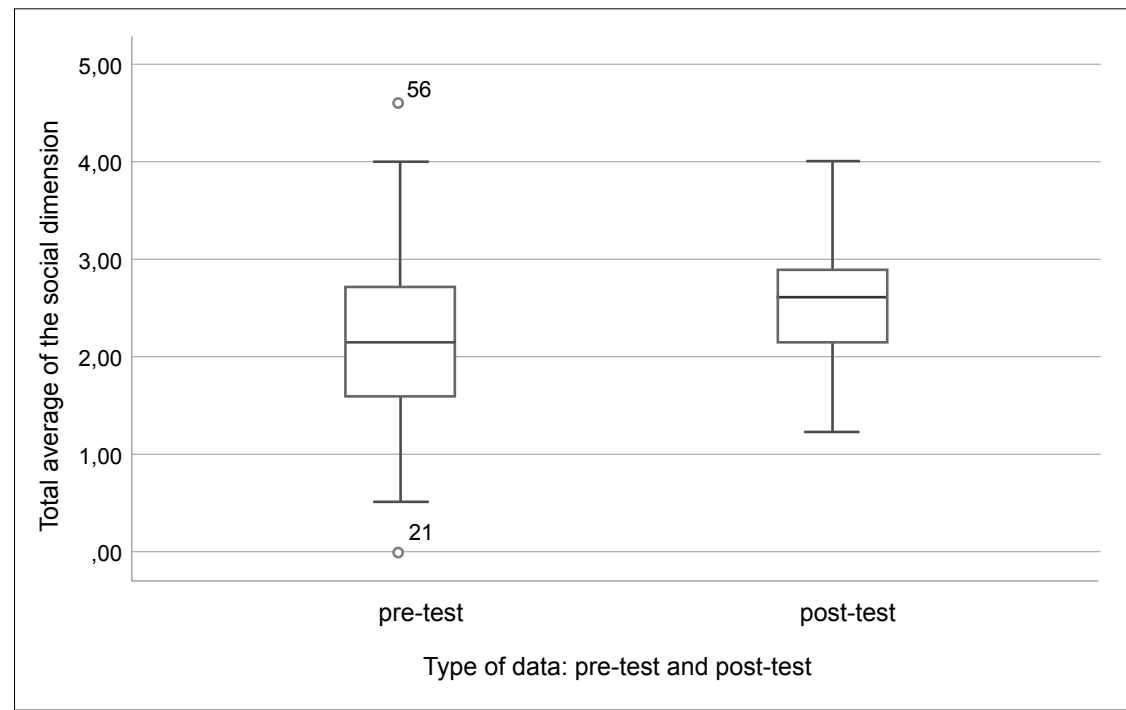

Figure 5. Box-and-whisker plot for the social dimension.

Source: own elaboration. 


\subsection{RESULTS ON THE ECOLOGICAL DIMENSION}

Figure 6 shows the box-and-whisker plot of the median distribution on the ecological dimension with a median valuation of 2.38 in the pre-test to a value of 3.06 for the post-test. After applying for a green business model training program, the perception of the feasibility of ecologically sustainable business models significantly improves.

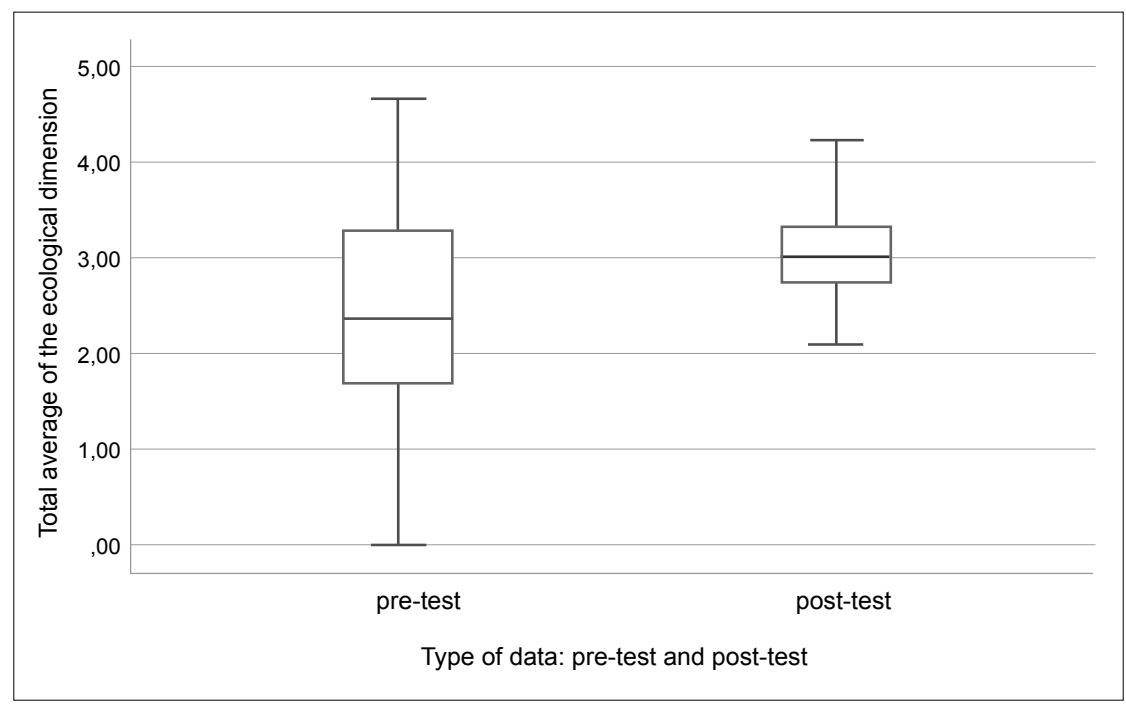

Figure 6. Box-and-whisker plot for the ecological dimension.

Source: own elaboration.

The application of median comparisons with the Wilcoxon test for related samples shows a value of the Wilcoxon statistic of $\mathrm{Z}=-4.959$ with $\mathrm{Sig} .=0.000$. The statistical test shows statistically significant evidence to reject the null hypothesis of equality of medians. Consequently, it can be concluded that the application of the training program positively influences the perception of the ecological dimension of a business model with environmental sustainability, with a design of an efficient production cycle of metabolites from the Shinus molle plant, from extraction, processing, product formulation, to the final disposal of its residues. 
Of the three dimensions evaluated, the ecological dimension is the one that evolves positively in the most significant ways, indicating that training programs in green business models based on environmental responsibility provide a greater degree of ecological awareness to offer solutions to the needs of alternative commercial products for consumption and export. In this context, the research aims to promote alternatives to sustainably producing inputs from the agricultural sector without promoting monocultures and without affecting ecosystems. For example, Molle plantations are an alternative that does not require sophisticated technologies or chemical substances that can change the ecological balance. In other words, if we only plant this plant and with minimal and natural care, we can develop and provide the raw material sustainably for those based on essential oils.

\subsection{RESULTS ON THE ENVIRONMENTAL SUSTAINABILITY INSTRUMENT}

Table 4 and Figure 7 show the average ranges. The sum of positive fields presents a value of 3461.50 higher than that of the negative degrees, with a value of 1003.50, showing significant differences between the medians of the post-test the pre-test.

Table 4. Wilcoxon signed-rank test for the environmental sustainability instrument.

\begin{tabular}{|c|c|c|c|c|}
\hline & & $\mathbf{N}$ & $\begin{array}{c}\text { Average } \\
\text { rank }\end{array}$ & $\begin{array}{c}\text { Sum of } \\
\text { ranks }\end{array}$ \\
\hline \multirow{4}{*}{$\begin{array}{l}\text { Total average of the post-test instrument - Total ave- } \\
\text { rage of the pretest instrument - Total average of the } \\
\text { post-test tool - Total average of the pretest instrument }\end{array}$} & Negative ranges & 28 & 35,84 & 1003,50 \\
\hline & Positive Ranks & 66 & 52,45 & 3461,50 \\
\hline & Ties & 0 & & \\
\hline & Total & 94 & & \\
\hline
\end{tabular}

Source: own elaboration. 


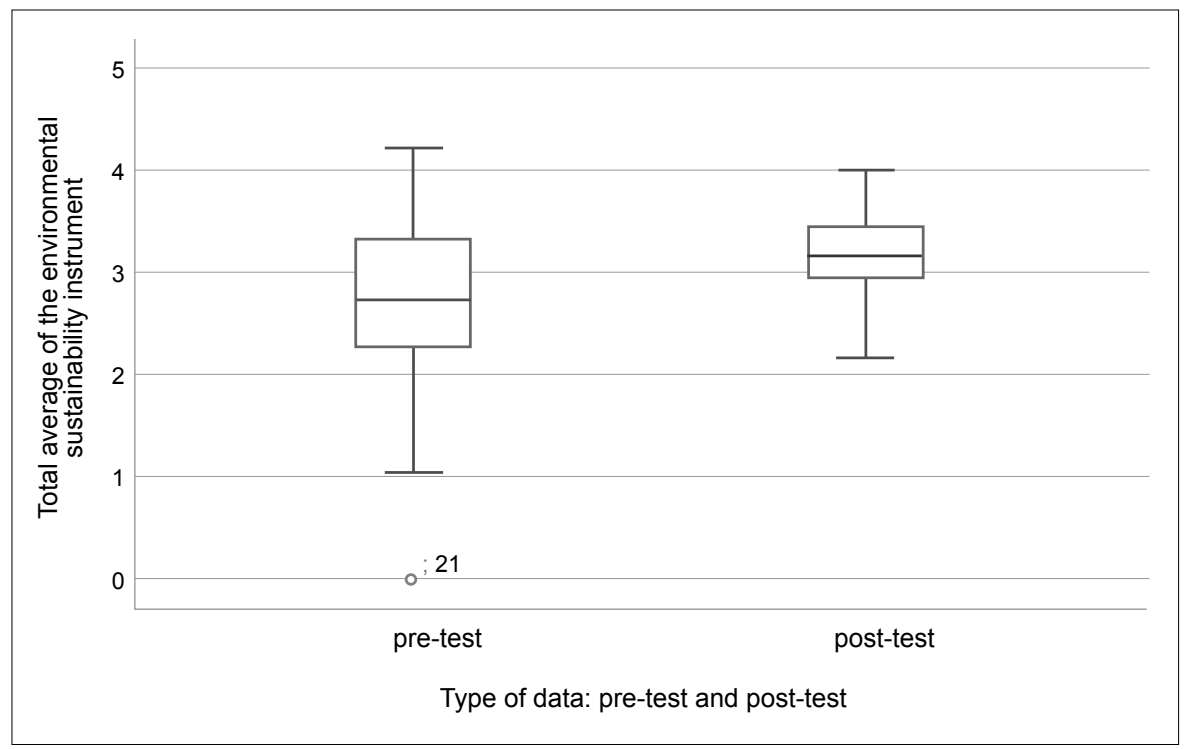

Figure 7. Box-and-whisker plot for the environmental sustainability instrument.

Source: own elaboration.

The application of median comparisons with the Wilcoxon test for related samples shows a Wilcoxon statistic value of $Z=-4.635$ with $\mathrm{Sig}$. $=0.000$. The statistical test shows statistically significant evidence to reject the null hypothesis of equality of medians. Consequently, it can be concluded that the application of the training program positively influences the perception of environmental sustainability of business models with a design of an efficient production cycle of metabolites from the Shinus molle plant, from extraction, processing, formulation of products, to the final disposal of their residues.

The ecological sustainability on which this study is based is based on the rationality and resilience of molle, which grows wild and without significant care. The first refers to the capacity to drastically reduce the models of consumerism based on sustainable use of natural resources. The second relates to changes in the rural dynamics so that the ecological balance is not irreversibly disturbed. It should be noted that the most devastating disturbances of ecosystems are the demanding culture of society for more demanding products in terms of quality and cost, which leads to maximizing production to reduce 
costs. It can be observed that commercial and industrial activities optimize waste management without reducing consumerism, which makes nature an inexhaustible source of resources, far from what the sustainable development paradigm implies.

\section{CONCLUSIONS}

About the pre-experimental design of the present research on a model of efficient and sustainable improvement of a production and commercialization system of molle essential oil (Schinus molle), the Wilcoxon $Z$ value, with a value of $Z=-4.635$ with Sig. $=0.000$ shows statistically significant evidence to reject the null hypothesis on the equality of medians. Based on the statistically significant results, it can be concluded that the application of strategic training programs from the academy, promoting production and commercialization systems of molle essential oil, Schinus molle, is practical, improving the levels of perception about the viability of promoting and managing endogenous, ecologically sustainable green business models.

Strategic planning for the development of endogenous agricultural zones requires research to rediscover the singularities of each rural zone. With proposals for self-managed or self-reliant development policies, Peru's sustainable development can be promoted. This conclusion constitutes a shared vision of a viable future that permeates and articulates civil organizations and their regional and rural institutions, the academy, which under the auspices of the state, can evaluate more research projects on endogenous and sustainable development models that contribute, first and foremost, to the welfare of farmers and rural areas.

About the economic dimension of the model of efficient and sustainable improvement of a production and commercialization system of molle essential oil (Schinus molle), the Wilcoxon $\mathrm{Z}$ value, with a $\mathrm{Z}=$ 1.646 with Sig. $=0.100$. The statistical test shows no statistical evidence to reject the null hypothesis on the equality of medians of the economic dimension. It can be concluded that the implementation of the programs on a business model with environmental sustainability framed in a design of an efficient 
production cycle of metabolites of the Schinus molle plant, from the extraction, processing, formulation of products, to the final disposal of their waste does not significantly influence the economic dimension about the fact that they should promote only economic returns. In other words, environmental awareness through globalization concludes that it is urgent to initiate projects on the rethinking and restructuring of business models focused on unsustainable utilitarianism over time to transform them into agroecological models with high sustainability indexes.

About the social dimension of the efficient and sustainable improvement model of a molle (Schinus molle) essential oil production and commercialization system, the Wilcoxon Z-value, with a value of $\mathrm{Z}=-4.044$ with Sig. $=0.000$. The statistical test shows statistical evidence to reject the null hypothesis on the equality of medians of the social dimension. It can be concluded that the implementation of the programs on a business model with environmental sustainability framed in a design of an efficient production cycle of metabolites of the Schinus molle plant, from the extraction, processing, formulation of products, to the final disposal of their residues, does positively influence the social dimension of the instrument.

These significant differences between the pre-test and post-test, about the social dimension of the environmental sustainability instrument, lead to the conclusion that any vision of sustainable development should consider the social dimension as a strategic factor and structuring axis of sustainable development, reversing the status quo that is based from its origins mainly on addressing the binomial economic dimension and ecological dimension to the detriment of social justice as an indissoluble part of ecological justice, i.e., socio-ecological sustainability should be pursued.

About the ecological dimension of the efficient and sustainable improvement model of a molle (Schinus molle) essential oil production and commercialization system, the Wilcoxon $Z$ value, $Z=-4.959$ with Sig. $=0.000$. The statistical test shows that there is statistical evidence to reject the null hypothesis on the equality of medians of the ecological dimension, and it can be concluded that the implementation of the programs on a business model with environmental sustainability framed in a design of an efficient 
production cycle of metabolites of the Schinus molle plant, from the extraction, processing, formulation of products, to the final disposal of its residues, does positively influence the ecological dimension of the instrument.

The significant differences in the medians between the pre-test and post-test of the ecological dimension show that based on permanent intervention and advisory programs, it is possible to develop green business systems more balanced about considerations and respect for nature, with a higher degree of resilience, less vulnerable to the contexts of supply and demand, with a great capacity for adaptation and reinvention, always in the search for the well-being of the farmer in reconciliation with his habitat.

As a conclusion, concerning the contrast of the hypotheses of this research, it is concluded that it is necessary to implement and strengthen interdisciplinary alliances of researchers in the academy, transcending their disciplinary field to generate transdisciplinary strategies based on the needs of social actors, the fundamental basis of endogenous sustainable development.

The training program on the canvas of business models for efficient and sustainable improvement of a production and marketing system for essential oils has shown that the articulation of projects between academia, civil society, and small farmers has potential, concerning the possibility of promoting sustainable development in an endogenous way insofar as agricultural sustainability must consider in a prevalent way the social dimension, the ecological size and finally the economic dimension. The present research results show that social and environmental awareness are strategic dimensions for initiating green enterprises.

From the results of the canvas application on models based on agricultural products, it is concluded that it is necessary to activate sustainable development strategies of endogenous nature, from rural areas to cities. Therefore, the guidelines that promote environmentally sustainable microenterprise models are viable to the extent that the projection and social extension systems of the universities fulfill the role of being the driving force so that, in a technical manner and following the purposes and goals of each green 
business model based on the agricultural system, it can be made viable through the promotion of the State.

\section{ACKNOWLEDGMENTS}

This paper has been possible to research due to obtaining and generating knowledge from different professionals. The authors wish to thank our university mentors for their support and guidance.

\section{REFERENCES}

Altiere, M. (2018). Agroecology. The Science of Sustainable Agriculture (2 ${ }^{\text {nd }}$ ed. Vol. 148). CRC Press.

Alvarado, K., Esenarro, D., Rodriguez, C., \& Vasquez, W. (2020). Lemna minor influence in the treatment of organic pollution of the industrial effluents. $3 C$ Tecnología. Glosas de innovación aplicadas a la pyme, 9(3), 77-97. https://ojs.3ciencias.com/index.php/3c-tecnologia/article/view/1072

Arias, F. (2006). Desarrollo sostenible y sus indicadores. Desarrollo Sostenible Y Sus Indicadores, 11, 200-229. http:/ / www.redalyc.org/articulo.oa?id=99616177008

Balvanera, P., Astier, M., Gurri, F. D., \& Zermeño-Hernández, I. (2017). Resiliencia, vulnerabilidad y sustentabilidad de sistemas socioecológicos en México. Revista Mexicana de Biodiversidad, 88, 141149. https://doi.org/10.1016/j.rmb.2017.10.005

Bautista, V. (2018). Química Industrial del Molle (Shinus molleL.). Autores de Argentina.

Carro-Suárez, J., \& Sarmiento-Paredes, S. (2017). La cultura organizacional y su influencia en la sustentabilidad empresarial. La importancia de la cultura en la sustentabilidad empresarial. Estudios Gerenciales, 33(145), 352-365. https://doi.org/10.1016/j.estger.2017.11.006 
Castañeda,J. S. (2014). Contextualización y enfoques en el estudio de comportamientos proambientales o ecológicos con miras a la perfilación del consumidor verde. Suma de Negocios, 5(10), 34-39. https://doi.org/10.1016/s2215-910x(14)70007-2

Castiblanco, G. (2007). La Economía ecológica. Una disciplina en busca de autor. Gestión y Ambiente, 10(3), 07-21. https://revistas.unal.edu.co/index.php/gestion/article/view/1424

Castiblanco, C. (2015). Cambio climático, economía ambiental y estilos de desarrollo. Indicadores de Sustentabilidad Opciones de Adaptación y Mitigación. Aspectos Distributivos Del Cambio Climático, $1-96$.

https://www.cepal.org/sites/default/files/courses/files/presentacion_carmenza_ castiblanco.pdf

Gordera, R. (2017). Globalización en crisis; por un desarrollo sostenible. Economía UNAM, 14(40), 3-12. https://doi.org/10.1016/j.eunam.2017.01.001

De Los Rios-Garmenado, I., Becerril-Hernandez, H., \& Rivera, M. (2016). La agricultura ecológica y su influencia en la prosperidad rural: Visión desde una sociedad agraria (Murcia, España). Agrociencia, 50(3), 375-389. http://www.scielo.org.mx/scielo.php?pid=S1405$31952016000300375 \&$ script=sci_abstract

Gavito, M. E., Wal, H. Van Der, Aldasoro, E. M., Ayala-orozco, B., Atenea, A., Cach-pérez, M., Casas-fernández, A., Fuentes, A., González-esquivel, G., Jaramillo-lópez, P., Martínez, P., Masera-cerruti, O., Pascual, F., Pérez-salicrup, D. R., Robles, R., \& Ruiz-mercado, I. (2017). Ecología, tecnología e innovación para la sustentabilidad: retos y perspectivas en México. Revista Mexicana de Biodiversidad, 88, 150-160. https://doi.org/https:// doi.org/10.1016/j.rmb.2017.09.001

González, G. A. (2012). Reflexiones del desarrollo local sostenible. eon. 
Hediger, W., \& Knickel, K. (2009). Multifunctionality and Sustainability of Agriculture and Rural Areas : A Welfare Economics Perspective. Fournal of Environmental Policy \& Planning, 11(4), 291-213. https://doi.org/10.1080/15239080903412453

Hernández, R., Hernández, G., \& Baptista, P. (2014). Metología de la Investigación (6. ${ }^{\text {a }}$ ed.). Mc Graw Hill Education.

Kammerbauer, J. (2001). Las dimensiones de la sostenibilidad: Fundamentos ecológicos, modelos paradigmáticos y senderos. Interciencia, 26(8), 353-359. https://www.semanticscholar.org/paper/ Las-dimensiones-de-la-sostenibilidad\%3A-fundamentos-y-Kammerbauer/9c8ad7c9500a697b2 d78a7419f836b380570b304

Larrouyet, M. G. (2015). Desarrollo sustentable. Origen, evolución y su implementación para el cuidado del planeta. http://ridaa.unq.edu.ar/handle/20.500.11807/154

Lehtonen, M. (2004). The environmental-social interface of sustainable development: Capabilities, social capital, institutions. Ecological Economics, 49(2), 199-214. https://doi.org/10.1016/j. ecolecon.2004.03.019

Lim, T. K. (2016). Edible Medicinal and Non-Medicinal Plants. In Edible Medicinal and Non-Medicinal Plants. https://doi.org/10.1007/978-3-319-26065-5

Paredes, P., Esenarro, D., Bernabe, J.J., y Quispe, W. (2020). Acceptability in the optimal formulation of chrysin with partial replacement of pituca flour. 3C Tecnología. Glosas de innovación aplicadas a la pyme. Edición Especial, Octubre 2020, 137-147.

Silva-Santamaría, L., \& Ramírez-Hernández, O. (2017). Evaluación de agroecosistemas mediante indicadores de sostenibilidad en San José de Las Lajas, Provincia de Mayabeque, Cuba. Revista Luna Azul, 44, 120-152. https://doi.org/10.17151/luaz.2017.44.8 
Strange, T., \& Bayley, A. (2012). Desarrollo Sostenible, Integrar la economía la sociedad y el medio ambiente. OCDE. https://dx.doi.org/10.1787/9789264175617-es

Velayos-Castelo, G. (2008). ¿Qué sostenibilidad?: una lectura desde la Filosofia Práctica. Papeles de Relaciones Ecosociales y Cambio Global, 101, 13-26. http://www.fuhem.es/media/ecosocial/file/ Sostenibilidad/Economía ecológica/Que_sostenibilidad_CarmenVelayos.pdf 
